\title{
THE INFLUENCE OF PILATES EXERCISE ON WOMEN'S ANTHROPHOMETRY INDICES, CORE MUSCLE PERFORMANCE AND HEART RATE CHANGES DURING THE SESSION
}

\author{
Vaiva Abramavičiūtė, Kristina Zaičenkovienė, Artūras Sujeta \\ Lithuanian Sports University, Kaunas, Lithuania
}

\begin{abstract}
Research background and hypothesis. Pilates exercises are used in fitness and in some forms of rehabilitation programs (Di Lorenzo, 2011). Pilates focuses on core body exercise and activation of transversus abdominis muscle (TrA), multifidus and pelvic floor muscles can also be used as an exercise programme controlling body mass and blood pressure. Little is known about the Pilates exercise intensity and heart rate changes during the practice session.

The aim of the current research was to study the impact of Pilates exercise on women's body weight, core muscle performance and to evaluate heart rate changes during the practice session.

Research methods included anthropometry measurements, heart rate and core muscle performance measures.

Research results. In the period of 8-week Pilates training we found that it had a significant impact on women's fat body mass and static core muscle endurance. Slightly decreasing tendency was found in BMI, but there were no statistically different changes between the results at the beginning and after 8-week training period. Measuring HR changes during the Pilates session we found that moderate HR was 98.2 (4.7) beats/min and maximum HR was 131.4 (7.2) beats/min. Maximum HR took approximately $10 \%$ and moderate HR $-90 \%$ of training period time.

Discussion and conclusions. We found that 8-week Pilates training period had a positive influence on the participants' core muscle performance, fat body mass and minor BMI reduction. As a result, Pilates exercises could be used for the prevention of low back pain and to reduce obesity. Slight HR changes during the session indicate that Pilates exercises may have implications for the rehabilitation of individuals who have high blood pressure and cannot go in for high intensity physical activity.
\end{abstract}

Keywords: BMI, heart rate, Pilates training, static endurance of core muscles.

\section{INTRODUCTION}

$\mathrm{P}$ ilates method is a physical fitness system which helps to relax and at the same time sustains the smallest inner body muscles. Most attention is paid to the correct spine position and strengthening inner small body muscles during the practice session (Crews, 2006).

Joseph Pilates recognized that motor functions of the brain controlled the mobility and stability of the body, activating specific muscles in a functional sequence at controlled speeds and emphasizing quality, precision, and control of movement (Gallagher, Kryzanowska, 2000).
Scientific research shows that exercising in Pilates provides higher muscle endurance (especially of inner body muscles), has a positive impact on body composition changes, and shows a tendency to regulate blood pressure (Jago et al., 2006; Rogers, Gibson, 2009), as well as to strengthen and stabilize back and abdominal muscles (Menacho et al., 2010).

Joseph Pilates is credited for labelling the core, or centre, "the powerhouse" (Weinberg, 2008). The general consensus regarding the anatomical boundaries of the "core" is from the pelvic floor 
inferiorly to the ribcage superiorly and is consistent with most of the current operative definitions (Akuthota, Nadler, 2004; Faries, Greenwood, 2007; Willardson, 2008). Centring is the focal point of the Pilates method. Abdominal hollowing, or the abdominal drawing-in manoeuvre (Endleman, Critchley, 2008) preferentially recruits $\operatorname{TrA}$, internal oblique, and multifidus muscles (Barnett, Gilleard, 2005; Hides et al., 2006).

Z. Ali and colleagues (2010) investigated Pilates training impact on overweight physically inactive women. Research sample included 15 women, $26( \pm 3)$ years of age. Results showed that Pilates training had a significant impact on the percentage fat body mass; it decreased by $7.3 \%$, fat body mass $(\mathrm{kg})$ decreased by $8.5 \%$. Hip measurement indices decreased by $4.6 \%$. However, total body mass and BMI indices remained unchanged (Ali et al., 2010).

In the 4-week 1 research with 11-year-old young girls, scientists measured heart rate (HR) during the session using Polar HR monitors. Results showed that moderate training activity was $75 \%$, mean HR was 104 beats/min (Jago et al., 2006).

The aim of the current research was to study the impact of Pilates exercise on women's body weight, core muscle performance and to evaluate heart rate changes during the practice session.

\section{RESEARCH METHODS}

From 26 women who took 8-week Pilates training session we selected 10 volunteering women who were included into the research sample. All the other women refused to take part in the research, but they also performed Pilates exercises with the groups. Women took an 8-week Pilates training sessions twice a week for one hour; we measured their body mass, fat body mass, core muscle endurance and observed HR changes during the session at the beginning and after 8-week Pilates training period. Anthropometric characteristics are presented in the Table.

Table. Anthropometric characteristics of the participants

\begin{tabular}{|c|c|}
\hline Index Participants & $n=10$ \\
\hline Age, years & $40.4(10.5)$ \\
\hline Height, cm & $167.1(2.8)$ \\
\hline Weight, kg & $64(10.2)$ \\
\hline
\end{tabular}

Research methods. At a baseline and after the 8-week training period, participants were weighted using Tanita TBF 300 (USA) scales and their BMI and fat body mass were calculated. The height of the participants was measured using wooden meter ruler.

Heart rate measurements were taken using Polar HR monitors. Resting heart rate was measured after the 10 min relaxation lying on the mat. Heart rate changes were presented by Polar Precision Performance computer programme (Figure 1). We analysed HR changes during the Pilates session. HR target zones were calculated using Karvonen target HR zones formula (Skidmore et al., 2008; Burke, 2002).

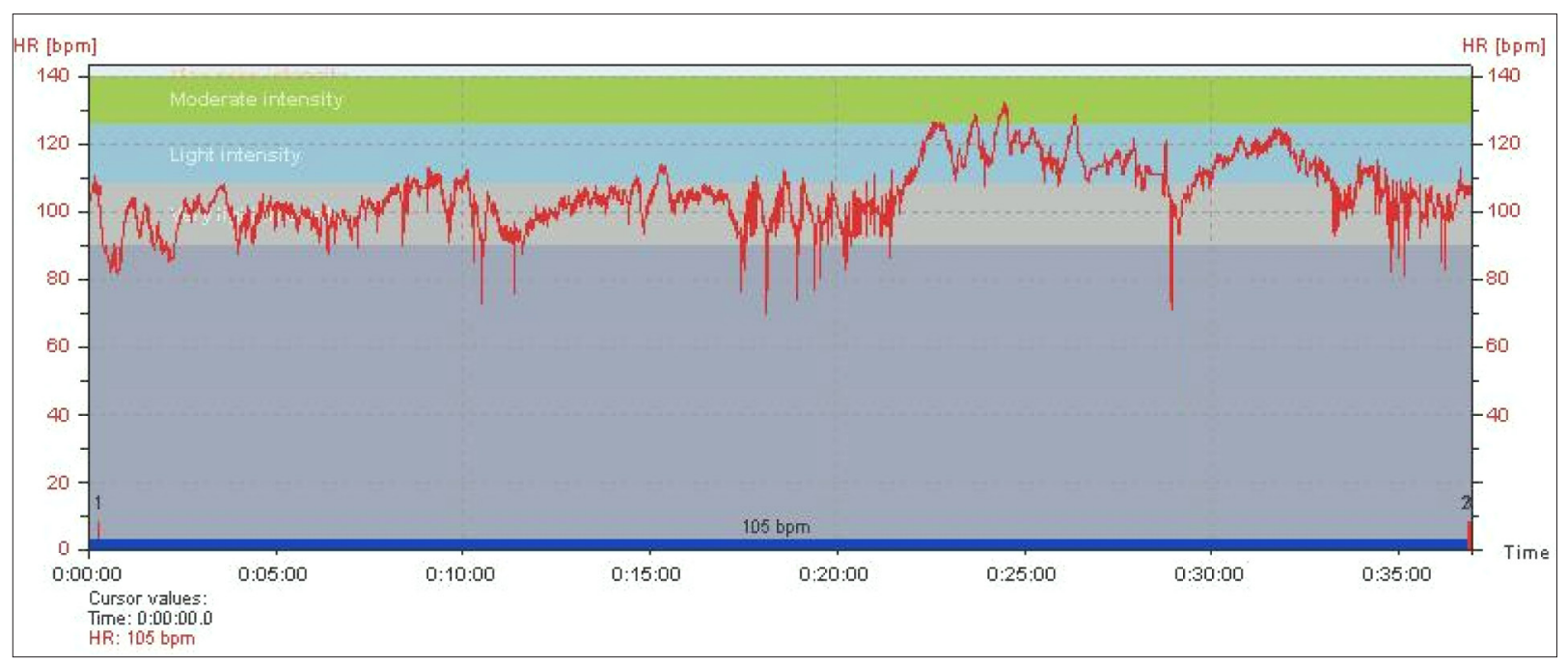

Figure 1. The original curve of one participant heart rate changes during the Pilates session 
Static core muscle endurance was measured using Stabilizer ${ }^{\mathrm{TM}}$ Pressure Bio-feedback device. Measurements weremade performing two exercises: lying on the back with bend legs (first exercise) on the floor and lying on the floor with band raised legs $90^{\circ}$ (second exercise). Stabilizer ${ }^{\mathrm{TM}}$ Pressure Bio-feedback was put under the participant's back and cuff was set at $40 \mathrm{~mm} \mathrm{Hg}$ of pressure, and then the exercise was performed attempting to maintain that pressure. We registered the time which the participant maintained unchanged cuff pressure.

Statistical analysis of the research data was carried out using "Polar Precision Performance", "Microsoft Excel" and "Statistica for Windows". The following parameters were calculated: arithmetic mean $(\mathrm{x})$, standard deviation $( \pm \mathrm{SD})$, ANOVA single factor analyses and index $p$ for statistical significance. The level of significance was set when $\mathrm{p}<0.05$.

\section{RESEARCH RESULTS}

Research results showed that Pilates training had a positive impact on women's BMI. At the beginning it was 23.4 (5.2) and after 8-week training it was 22.8 (4.5). There were no statistically significantly different changes $(\mathrm{p}=0.082)$, but we observed slightly decreasing BMI tendency (Figure 2).

Anova showed statistically decreased percentage of body fat mass $(\mathrm{p}=0.003)$ compared to the values at the beginning $29.8(7.4) \%$ and after 8 -week Pilates training 28.4 (7.6)\%.

Anova showed statistically significantly different changes between core muscle static endurance results during the first exercise at the beginning of Pilates training 16.3 (4) $\mathrm{s}$ and after 8-week period 20.8 (3.3) s ( $\mathrm{p}=0.003)$ (Figure 4).

Statistically significantly different changes $(p=0.0001)$ were also found between core muscle

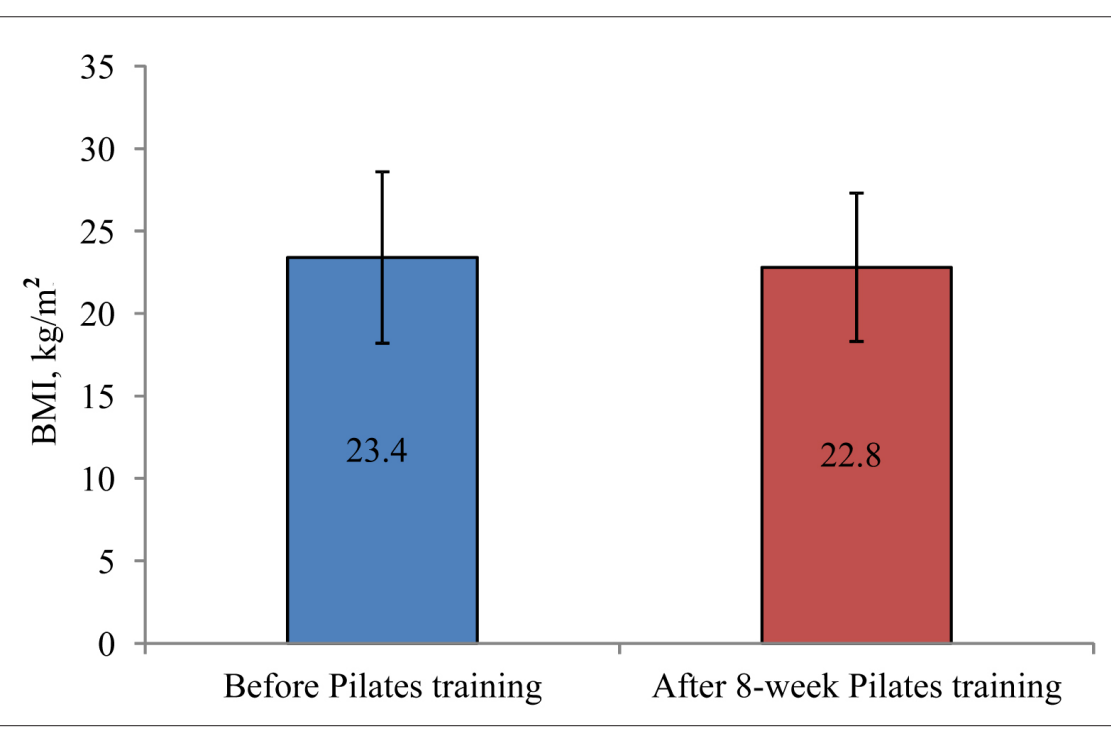

Figure 2. Women's BMI changes before and after 8-week Pilates training period

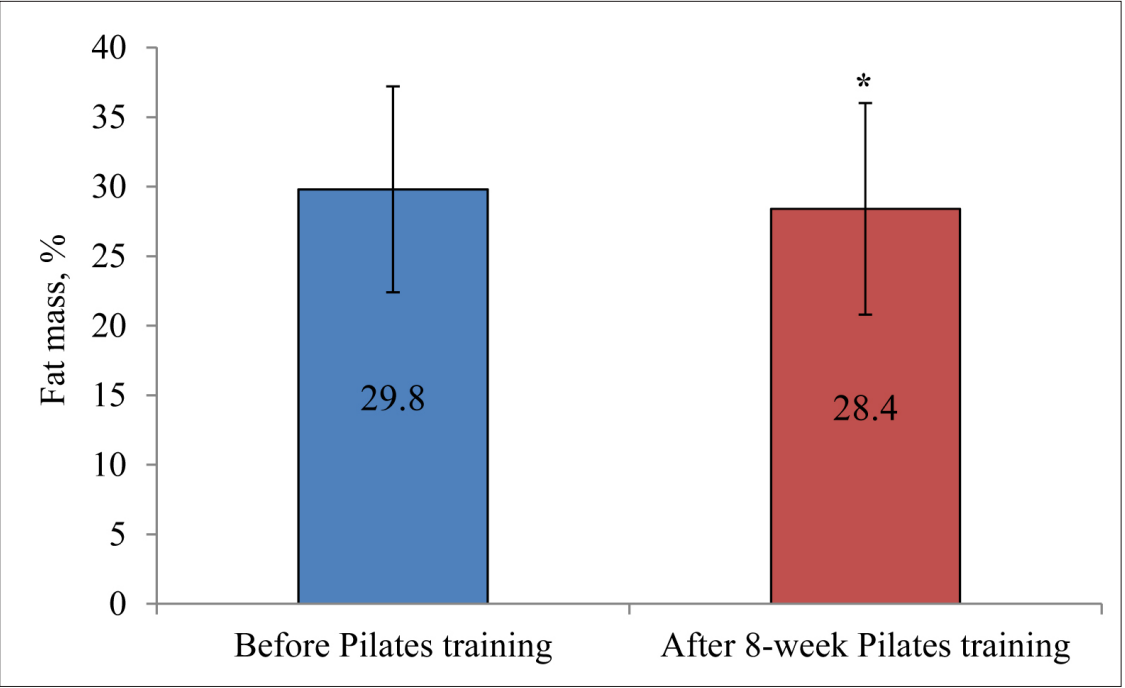

Figure 3. Women's fat body mass before and after 8-week Pilates training period

Note. $*$ - statistically significant difference $(p<0.05)$. 
static endurance results performing the second exercise. At the beginning the result was 27 (4.2) s and after Pilates training period it improved to 33.8 (2.9) s (Figure 5).

Analysing HR changes during the session we found that women's resting HR was 74.6
(3.3) beats/min, moderate HR during the session was 98.2 (4.7) beats/min and maximum HR was 131.4 (7.2) beats/min (Figure 6). Maximum HR took about $10 \%$ of the training period time, and moderate HR - about $90 \%$ of the training period time (Figure 7).
Figure 4. Core muscle static endurance results during the first exercise

Note. * - statistically significant difference $(\mathrm{p}<0.05)$.

Figure 5. Core muscle static endurance results during the second exercise

Note. * - statistically significant difference $(\mathrm{p}<0.05)$.

Figure 6. Resting, moderate and maximum heart rate values
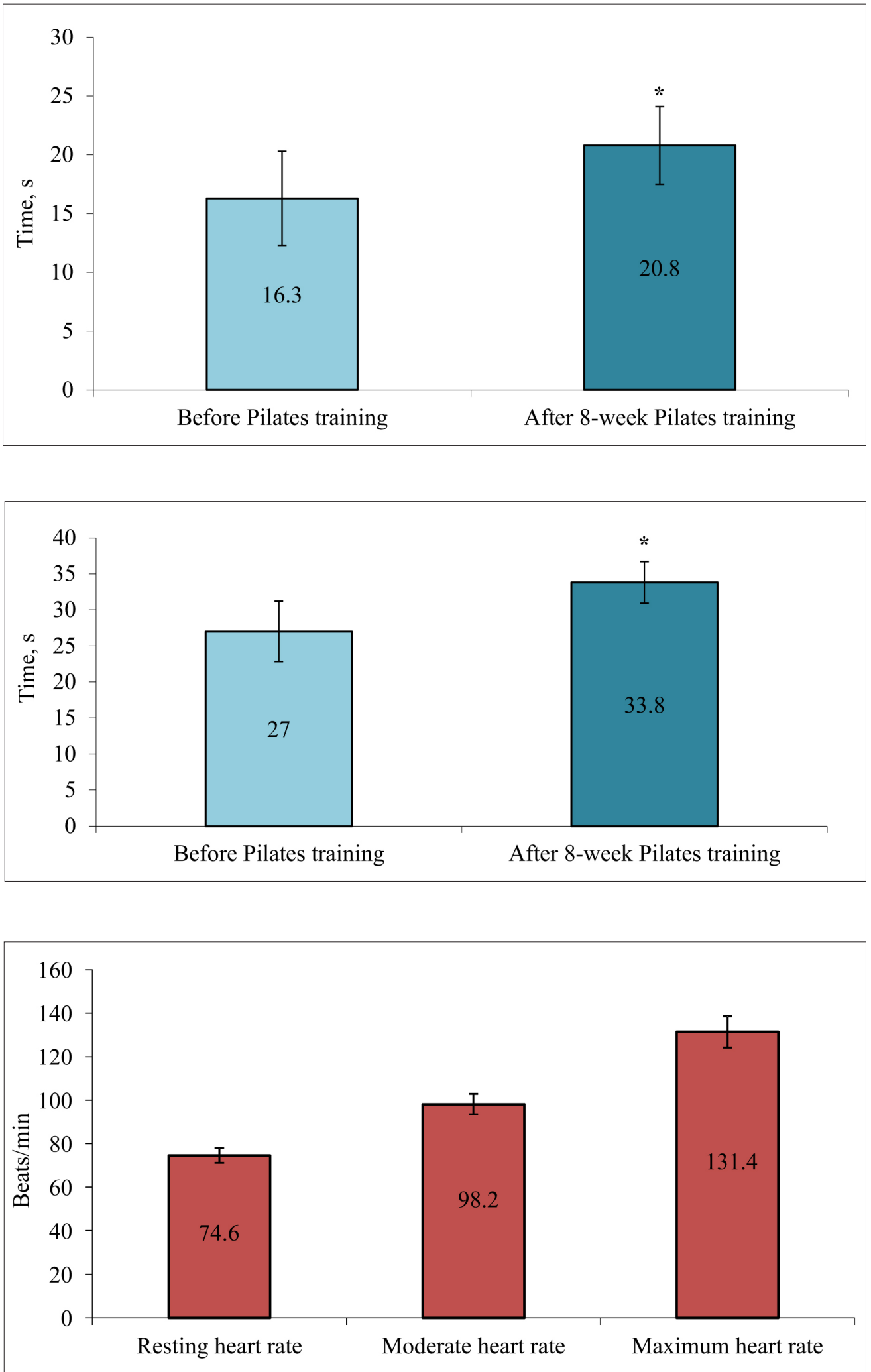


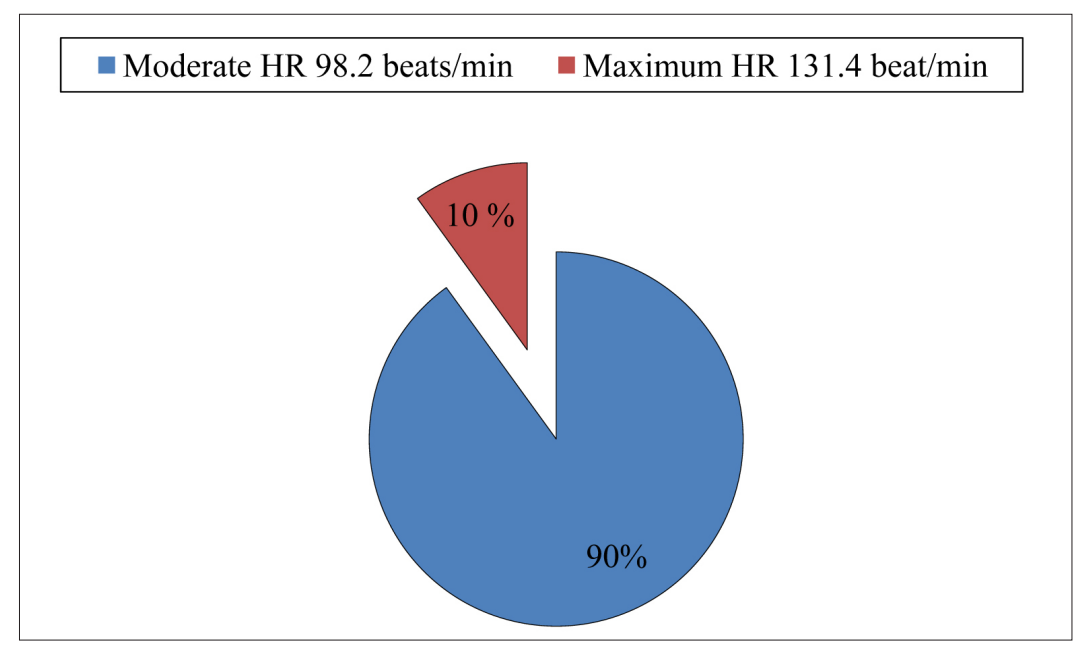

Figure 7. The spread of Heart rate during the session

\section{DISCUSSION}

According to numerous scientific studies, Pilates method is an effective physical fitness method (Kloubec, 2010; Dunleavy, 2010). Pilates training helps to reduce obesity (Jago et al., 2006; Sekendiz et al., 2006; Kloubec, 2010). In our research women's fat body mass decreased after 8 -week Pilates training period and we also observed a decreasing tendency of BMI. These results mainly coincided with R. Jago and colleagues' (2006) investigations proving that 4-week Pilates training had a significant impact on BMI and improved blood pressure of 11-year-old girls. A randomized trial of 30 girls (10 to 12 years old) were offered free Pilates classes (Jago, 2006). Sixteen girls (intervention group) participated in group mat Pilates classes 5 days per week, 1 hour per session, for a 4-week period. The body mass index (BMI) percentile of these young girls was lowered in this pilot study. There was a 3.1-percentile reduction in the BMI in the treatment group, while the control group increased by 0.8 percentiles.

K. Rogers and A. L. Gibson (2009) found that after 8 -week Pilates training period body fat mass decreased by $1.2 \%$. Our research results are similar: fat body mass decreased by $1.47 \%$.

Using real-time ultrasound, I. Endelman and D. J. Critchley (2008) demonstrated that Pilates technique of abdominal hollowing was effective in recruiting the Transversus abdominis (TrA) muscle and the internal obliques. Twenty-six healthy participants with at least 6 months of classical Pilates training were recruited for a repeated measures study to analyse Pilates exercises with or without the abdominal drawing-in manoeuvre (Ultrasound was used to detect activity in the TrA and internal oblique muscles). Pilates exercises activated the TrA and internal oblique, but they did not function independently (Endleman, Critchley, 2008).

J. Kloubec's (2010) research dealt with 12 weeks of Pilates training for middle aged men and women twice a week for $60 \mathrm{~min}$, which improved abdominal and upper body muscle endurance and also had a positive effect on the improvement of legs muscle flexibility compared to the results of the control group before and after 12-week training period. In our research core muscle static endurance improvements were seen after an 8-week Pilates training period.

L. Herrington and R. Davies (2005) also observed that Pilates exercises improved abdominal muscles endurance and stability of core muscles in girls. J. L. Fonceka with colleagues (2009) found that Pilates exercises were the perfect way for people who felt pain or had problems with the back muscles.

We found that during Pilates training session women's moderate HR was 98.2 (4.7) beats $/ \mathrm{min}$ and this HR was observed during nearly $90 \%$ of session time. Maximum HR was 131.4 (7.2) beats/ min and this HR was seen only in about $10 \%$ of Pilates training session time. It can be concluded that Pilates exercises perfectly fit for persons with high blood pressure who cannot practice high intensity physical activity. R. Jago et al. (2006) found that moderate HR during Pilates exercises in young girls' group was 104 beats $/ \mathrm{min}$. J. M. Schroeder and colleges (2002) also measured HR changes during Pilates session and they found that HR changes during the session were from $86.0+14.34$ beats $/ \mathrm{min}$ to $105.8+15.53$ beats $/ \mathrm{min}$. It 
could be stated that this intensity of exercises was too low for improving heart muscle endurance.

\section{CONCLUSION AND PERSPECTIVES}

We found that 8 -week Pilates training period had a positive effect on the participants' core muscle performance, fat body mass and minor BMI reduction. As a result, Pilates exercises could be used for the prevention of low back pain and to reduce obesity. Slight HR changes during the session indicate that Pilates exercises may have implications for the rehabilitation of individuals who have high blood pressure and cannot practice high intensity physical activity.

\section{REFERENCES}

Akuthota, V., Nadler, S. F. (2004). Core strengthening. Archives of Physical Medicine and Rehabilitation, 85 (3), 86-92.

Ali, Z. O., Esfarjani, F., Bambaeichi, E., Marandi, M. (2010). The effects of Pilates exercise on blood pressure and selective physical fitness components in sedentary overweight females. British Journal of Sports Medicine, 44 (Suppl. I), 1-28.

Barnett, F., Gilleard, W. (2005). The use of lumbar stabilization techniques during the performance of abdominal strengthening exercise variations. Journal of Sports Medicine and Physical Fitness, 45, 193-201.

Burke, E. R. (2002). Heart Rate ABCs. Better Nutrition, $64(8), 48$.

Crews, L. (2006). Pilates. Philosophy and Biomechanics. American Fitness, 7 (8), 58-62.

Dunleavy, K. (2010). Pilates fitness continuum: Postrehabilitation and prevention Pilates fitness programs. Rehabilitation Management, 23 (9), 10, 12-15.

Endleman, I., Critchley, D. J. (2008). Transversus abdominis and obliquus internus activity during Pilates exercises: Measurement with ultrasound scanning. Archives of Physical Medicine and Rehabilitation, 89, 2205-2212.

Faries, M. D., Greenwood, M. (2007). Core training: stabilizing the confusion. Strength \& Conditioning Journal, 29, 10-25.

Fonceka, J. L., Magini, M., de Freitas, Th. (2009). Laboratory gait analysis in patients with low back pain before and after a Pilates intervention. Journal of Sport Rehabilitation, 18 (2), 269-282.

Gallagher, S. P., Kryzanowska, R. (2000). The Joseph H. Pilates Archive Collection. Philadelphia, PA: Bain Bridge Books.

Herrington, L., Davies, R. (2005). The influence of Pilates training on the ability to contract the Transversus abdominis muscle in asymptotic individuals. Journal of Bodywork and Movement Therapies, 9, 52-57
Hides, J., Wilson, S., Stanton, W. et al. (2006). An MRI investigation into the function of the transversus abdominis muscle during "drawing in" of the abdominal wall. Spine, 31, 175-178.

Jago, R., Jonker, M. L., Missaghian, M., Baranowski, T. (2006). Effect of 4 weeks of Pilates on the body composition of young girls. Preventive Medicine, 42 (3), 177-180.

Kloubec, J. (2010). Pilates for improvement of muscle endurance, flexibility, balance, and posture. The Journal of Strength and Conditioning Research, 24 (3), 661-667. Di Lorenzo, C. E. (2011). Pilates: What is it? Should it be used in rehabilitation? Sports Health, 3 (4), 352-361.

Menacho, M. O., Obara, K., Conceição, J. S. et al. (2010). Electromyographic effect of mat Pilates exercise on the back muscle activity of healthy adult females. Journal of Manipulative and Physiological Therapeutics, 33 (9), 672-668.

Rogers, K., Gibson, A. L. (2009). Eight-week traditional mat Pilates training-program effects on adult fitness characteristics. Research Quarterly for Exercise \& Sport, 80 (3), 569-574.

Schroeder, J. M., Crussemeyer, J. A., Newton, S. J. (2002). Flexibility and heart rate response to an acute Pilates reformer session. Medicine \& Science in Sports \& Exercise, 5 (34), 258.

Sekendiz, B., Altun, O., Korkusuz, F., Akin, S. (2006). Effects of Pilates exercise on trunk stength, endurance and flexibility in sedentary adult females. Journal of Bodywork and Movement Therapies, 11 (4), 318-326.

Skidmore, F, M., Patterson, S, L., Shulman, L, M., Sorkin, J, D., Macko, R, F. (2008). Pilot safety and feasibility study of treadmill aerobic exercise in Parkinson disease with gait impairment. Journal of Rehabilitation Research \& Development, 45 (1), 117-124.

Weinberg, J. (2008). Level 2: Romania's Pilates Senior Teacher Trainer, True Pilates New York [Pilates teacher training certification]. New York, NY: True Pilates.

Willardson, J. M. (2008). A periodized approach to core training. ACSM Health and Fitness Journal, 12, 7-13. 


\title{
PILATES PRATIMŲ POVEIKIS MOTERŲ ANTROPOMETRINIAMS RODIKLIAMS BEI LIEMENS RAUMENŲ IŠTVERMEI IR ŠIRDIES SUSITRAUKIMŲ DAŽNIO KAITAI PRATYBŲ METU
}

\author{
Vaiva Abramavičiūtė, Kristina Zaičenkovienė, Artūras Sujeta
}

Lietuvos sporto universitetas, Kaunas, Lietuva

\begin{abstract}
SANTRAUKA
Tyrimo pagrindimas ir hipoteze. Pilates pratimai plačiai taikomi sveikatinimo srityje, kaip viena iš reabilitacijos formų (Di Lorenzo, 2011). Pilates programos pagrindinis tikslas yra giliujų liemens raumenų, tokių kaip skersinis pilvo, dauginis dubens dugno, aktyvavimas. Taip pat šie pratimai gali būti naudojami kaip kūno svorio ir kraujo spaudimo reguliavimo programa. Aptikta nedaug studijų, kurių metu nagrinèta širdies susitraukimų dažnio kaita Pilates pratybu metu.

Tikslas - nustatyti Pilates pratimų poveiki moterų antropometriniams rodikliams, liemens raumenų ištvermei ir nustatyti širdies susitraukimo dažnio kaitą Pilates pratybų metu.

Metodai: antropometrija (Tanita TBF 300, JAV), pulsometrija (Polar HR), liemens raumenų ištvermès nustatymas (Stabilizer ${ }^{\mathrm{TM}}$ Pressure Bio-feedback), matematinè statistika.

Rezultatai. Po 8 savaičių Pilates pratybų nustatyta, kad jos teigiamai paveikè moterų riebalinę kūno masę ir liemens raumenų statinę ištvermę. Buvo pastebèta KMI rodikliu mažejimo tendencija, nors statistiškai reikšmingas rodikliu pokytis nebuvo nustatytas. Stebint širdies susitraukimų dažnio (ŠSD) kaitą pratybų metu nustatyta, kad vidutinis ŠSD buvo 98,2 $(4,7)$ tv./min, maksimalusis - 131,4 $(7,2)$ tv./min. Maksimalusis ŠSD sudaro apie 10\% pratybu laiko, vidutinis $-90 \%$.

Aptarimas ir išvados. Pilates pratybos teigiamai veikia moterų liemens raumenų statinę ištvermę, riebalinę kūno masę bei KMI rodiklio mažèjima. Ivertinant rezultatus galima būtų teigti, kad Pilates pratybos yra tinkamos nugaros skausmų bei antsvorio prevencijai. Nedideli ŠSD pokyčiai pratybų metu rodo, kad tokio pobūdžio pratybos tinka reabilitacijos metu tiems asmenims, kurie turi padidejusi kraujo spaudimą ir negali užsiimti jokia kita intensyvia fizine veikla.
\end{abstract}

Raktažodžiai: širdies susitraukimu dažnis (ŠSD), kūno masės indeksas (KMI), Pilates pratybos, liemens raumenų statinè jëgos ištvermè. 